Egyptian Journal of Aquatic Biology \& Fisheries

Zoology Department, Faculty of Science,

Ain Shams University, Cairo, Egypt.

ISSN $1110-6131$

Vol. 24(7): 13 - 21 (2020)

www.ejabf.journals.ekb.eg

\title{
A survey on the quality of fresh water used in some aquaculture and agricultural Egyptian areas and its impact on soil
}

\author{
Adel S. El-Hassanin ${ }^{1}$, Magdy R. Samak ${ }^{1}$, Ghadir A. El-Chaghaby ${ }^{2 *}$ and \\ Soliman R. Radwan ${ }^{2}$ \\ ${ }^{1}$ Department of Natural Resources, Faculty of African Postgraduate Studies, Cairo \\ University, Egypt \\ ${ }^{2}$ Regional Center for Food and Feed, Agricultural Research Center, Giza, Egypt \\ *Corresponding author:ghadiraly@yahoo.com
}

\section{ARTICLE INFO}

\section{Article History:}

Received: Sept. 5, 2020

Accepted: Oct. 4, 2020

Online: Oct. 9, 2020

\section{Keywords:}

Fresh water;

agriculture;

anions;

cations;

heavy metals;

soil quality

\section{INTRODUCTION}

Water quality is an important factor that impacts all kinds of life on earth. The present work is a survey of water quality in different Egyptian agricultural areas. Water samples were collected from two sites in Al-Dakahlia governorate (Kafr Bahia "site1" and Meit Mohsen "site2") and one site in Alexandria governorate (Al-Amereya "site3"). Samples were analyzed to determine some physiochemical properties as well as the concentration of some important anions, cations, and heavy metals. The analysis results revealed that the electric conductivity of water ranged from 0.438 in "site 2 " to $0.626 \mathrm{dS} / \mathrm{min}$ "site3". Also, the total dissolved solids values ranged from 275 to $394 \mathrm{mg} / \mathrm{l}$ in "site2" and "site3", respectively. Data showed that the levels of almost all anions and cations in the water samples were in the ranges set by FAO for irrigation water, the exceptions were nitrates $\left(\mathrm{NO}_{3}{ }^{-}\right)$in site2, ammonia $\left(\mathrm{NH}_{4}{ }^{+}\right)$in sites 2 and 3, potassium $\left(\mathrm{K}^{+}\right)$in sites 1 and 3 and magnesium $\left(\mathrm{Mg}^{2+}\right)$ in site 2 . Since water quality and agriculture have many complex interactions, the following parameters were also calculated: Sodium adsorption ratio (SAR), Kelly's ratio (KR), percentage of sodium (Na \%), and Magnesium Ratio. The SAR value of the water samples varied from 1.33 to 3.61. Kelly's ratio ranged from 0.405 to 1.00 . The $\mathrm{Mg}$ ratio values in the study sites were $<50 \%$. In order to check the impact of water on the nearby soils, the concentrations of elements in the soils from the studied sites were determined and compared to the maximum allowable concentration of elements in soil and the results indicated good soil conditions. In conclusion, the results showed that the water used for irrigation in the studied sites has no levels of contamination and this is also reflected in the surrounding soil. It is recommended to perform monitoring studies regularly to avoid any sudden problems.

Freshwater is vital to human life and its quality is of global concern. The Nile River is Egypt's life artery and is the main freshwater resource needed for almost all drinking and irrigation water requirements (Abdel-Satar et al., 2017). 
The quality of Nile water is of significant concern due to the growth of industrial, farming and recreational operations in addition to the poor organized irrigation and sewage infrastructure (Goher et al., 2015).

Water quality determines the functions of nearly every aspect of water resource management and usage. The surface water wealth in most developing economies is the engine of their agricultural and domestic development. Egypt is stressed because of aridity, limited natural water resources and increased water demand(Angelakis $\boldsymbol{e t}$ al., 2020). In Egypt, the main source of fresh water is the River Nile (Rashad et al., 2019a). Agriculture is the major consumer of fresh water, consuming 80-85 per cent of water resources (Abuzaid, 2017).

In Egypt only, the Nile from Aswan to the delta barrage receives wastewater from 124 point sources, of which 67 are agricultural drains; the remainder are industrial sources (El Gohary, 2015). Major pollutants in agricultural drains are salts, nutrients, pesticide residues, pathogens and toxic organic and inorganic pollutants (El-Sheekh, 2009).

In agricultural production activities, with the dynamic action of irrigation water, various pollutants (nutrients, pesticides, bacteria, etc.) spread from the soil to the water in the form of low concentration and broad range through agricultural surface runoff, farmland drainage and underground leakage (Wang et al., 2019). Also the use of fertilizers to enhance soil properties, crops productivity and nutrient quality (Rashad et al., 2019b) may cause accumulation of some elements in the soil.

For the past half century the impact of irrigation water composition on soil properties has been a priority for crop production. Previous studies of water quality issues, and the suitability of freshwater sources for irrigation, focused primarily on understanding potential soil salinity, fertility and crop growth problems (Malakar et al., 2019). It is also important to indicate that besides the agricultural use, water quality is equally essential for aquaculture practice and aquatic environment (Hoque et al., 2020).

Farmers are usually using irrigation water for planting crops and also for aquaculture purposes. Thus continuous monitoring of water quality is essential for avoiding the occurrence of any sudden contamination. The present study aims at monitoring the quality of water used for irrigation-around some Egyptian agricultural soils as well as the influence of water quality on these soils.

\section{MATERIALS AND METHODS}

\section{1- Sampling sites}

Water samples from irrigation canals were obtained from two sites (Kafr Bahia and Meit Mohsen) at Meit Ghamr in Al-Dakahlia governorate and one site (Al-Amereya) in Alexandria governorate. Also agricultural soil samples from the same agricultural areas were collected.

\section{2- Water analysis}

Samples were collected along the irrigation canals using grab technique. Sampling containers were immersed below the surface level to about $15 \mathrm{~cm}$ and inclined against the direction of flow (Onosemuode et al., 2016) . 
The water analysis was carried out using the procedures of the standard methods of analysis of water and wastewater (APHA, 2005). The analysis parameters included: water salinity, electric conductivity, total dissolved solids, major anions and cations in addition to some heavy metals. Add the instruments used for analysis and their models.

\section{3- Agricultural soil analysis}

Sub-surface soil samples $(15-30 \mathrm{~cm})$ were collected from the three studied areas using a tabular sampling auger. The samples were air-dried at room temperature for two weeks and then crushed to pass through $2 \mathrm{~mm}$ mesh sieve. Samples were subjected to analysis for total and available macro/ microelements and some heavy metals. The samples for total elements concentration were digested following the "AOAC official method 990.08" (Hegazy et al., 2011). Whereas for available elements concentration, soil samples were extracted with $0.5 \mathrm{M}$ solution of ammonium acetate and $0.02 \mathrm{M}$ EDTA as previously mentioned by (El-Hassanin et al., 2020). The concentrations of elements were then determined using inductively coupled plasma (ICP Ms/Ms QQQ8800 Agilent).

\section{4- Calculated parameters}

Sodium adsorption ration (SAR) is calculated as (Alobaidy $\boldsymbol{e t}$ al., 2010):

$\mathrm{SAR}=[\mathrm{Na}+] / \sqrt{ } 0.5([\mathrm{Ca} 2+]+[\mathrm{Mg} 2+])$

Where $[\mathrm{Na}+],[\mathrm{Ca} 2+]$ and $[\mathrm{Mg} 2+]$ are the concentrations of sodium, calcium and magnesium in (meq/l).

The sodium percentage $(\mathrm{Na} \%)$ is calculated as follows (Alobaidy $\boldsymbol{e t}$ al., 2010):

$\mathrm{Na} \%=\left[\left(\mathrm{Na}^{+}+\mathrm{K}^{+}\right) /\left(\mathrm{Ca}^{+2}+\mathrm{Mg}^{+2}+\mathrm{Na}^{+}+\mathrm{K}^{+}\right)\right] \times 100$

Kelly's ratio (KR) is calculated as follows (Shah et al., 2019):

$\mathrm{KR}=\mathrm{Na}+/ \mathrm{Ca}^{2+}+\mathrm{Mg}^{2+}$, where the ionic concentration are in $\mathrm{mg} / \mathrm{Kg}$.

Magnesium ratio was calculated by the following equation (Singh et al., 2020):

$\mathrm{Mg}$ ratio $=\left[\mathrm{Mg}^{2+} /\left(\mathrm{Ca}^{2+}+\mathrm{Mg}^{2+}\right)\right] \times 100$

\section{5- Statistical Analysis}

All measurements were done in three replicates and the mean values \pm standard deviation were presented. The Excel software for windows was used for computing the results.

\section{RESULTS AND DISCUSSION}

Among soluble constituents in water, common major and secondary constituents are $\mathrm{Ca}, \mathrm{Mg}, \mathrm{Na}, \mathrm{Fe}, \mathrm{B}, \mathrm{HCO}_{3}, \mathrm{SO}_{4}$, and $\mathrm{Cl}$, whereas, minor or trace constituent are As, $\mathrm{Cd}, \mathrm{Cr} . \mathrm{Cu}, \mathrm{Mn}, \mathrm{P}$ and $\mathrm{Zn}$. Water contamination has a direct effect on the health of inhabitants, aquatic resources flora and fauna (Hoque et al., 2020).

Data in table 1 show some physical and chemical parameters of water samples collected from the studied areas. The data revealed that the salinity in terms of total dissolved solids and electric-conductivity values of water samples from the three studied sites are within the accepted ranges for irrigation water (Shahinasi and Kashuta, 2008) (Ayers and Westcot, 1985).

Depending on the type and quantity of the dissolved salts, water used for irrigation can vary greatly in quality. Salts are present in relatively low, but substantial quantities in irrigation water. A water quality salinity problem arises when the cumulative quantity of salts in the irrigation water is such that the salts accumulate in the root zone to the degree that crop yields are adversely affected (Ayers and Westcot, 1985). 
Many trace elements, some organic compounds and also sodium, chloride, boron are toxic at very low concentration. In general, supplies of irrigation produce very small concentrations of these trace elements, and are not problematic (Shahinasi and Kashuta, 2008).

Table (1): Water quality characteristics

\begin{tabular}{|c|c|c|c|c|}
\hline \multirow{2}{*}{ Properties } & \multicolumn{3}{|c|}{ Sampling sites } & \multirow{2}{*}{$\begin{array}{c}\text { Desired range } \\
\text { (Herrmann and } \\
\text { Bucksch, 2014) and } \\
\text { FAO guidelines } \\
\text { (Arshad and Shakoor, } \\
\text { 1987) }\end{array}$} \\
\hline & $\begin{array}{l}\text { Kafr-Bahia } \\
\quad \text { Site } 1\end{array}$ & $\begin{array}{l}\text { Meit- Mohsen } \\
\text { Site } 2\end{array}$ & $\begin{array}{l}\text { Al-Amereya } \\
\text { Site } 3\end{array}$ & \\
\hline $\mathrm{EC}(\mathrm{dS} / \mathrm{m})$ & $\begin{array}{c}0.573 \\
\pm 0.004726\end{array}$ & $\begin{array}{c}0.438 \\
\pm 0.079513\end{array}$ & $\begin{array}{c}0.625 \\
\pm 0.028219\end{array}$ & $<0.7$ \\
\hline TDS (mg/l) & $\begin{array}{c}361 \\
\pm 3.21455\end{array}$ & $\begin{array}{c}275 \\
+51.73329\end{array}$ & $\begin{array}{c}394 \\
\pm 17.5784\end{array}$ & $<450$ \\
\hline Cl (mg/l) & $\begin{array}{c}47.31 \\
\pm 0.195021\end{array}$ & $\begin{array}{c}163.39 \\
\pm 66.85146\end{array}$ & $\begin{array}{c}114.99 \\
\pm 38.96297\end{array}$ & $<140$ \\
\hline $\mathrm{NO}_{3}(\mathrm{mg} / \mathrm{l})$ & $\begin{array}{c}2.19 \\
\pm 0.439356\end{array}$ & $\begin{array}{c}7.18 \\
\pm 2.638712\end{array}$ & $\begin{array}{c}3.59 \\
\pm 0.702875\end{array}$ & $<5$ \\
\hline $\mathrm{PO}_{4}(\mathrm{mg} / \mathrm{l})$ & $\begin{array}{c}0.93 \\
\pm 0.037859\end{array}$ & N.D & $\begin{array}{c}1.35 \\
\pm 0.227156\end{array}$ & $0-2$ \\
\hline $\mathrm{SO}_{4}(\mathrm{mg} / \mathrm{l})$ & $\begin{array}{c}50.58 \\
\pm 0.163707\end{array}$ & $\begin{array}{c}247.09 \\
\pm 113.2992\end{array}$ & $\begin{array}{c}90.34 \\
\pm 22.8922\end{array}$ & $<400$ \\
\hline $\mathrm{Na}(\mathrm{mg} / \mathrm{l})$ & $\begin{array}{c}50.52 \\
\pm 2.736933\end{array}$ & $\begin{array}{c}149.89 \\
+56.01765\end{array}$ & $\begin{array}{c}80.36 \\
\pm 17.20508\end{array}$ & $0-50$ \\
\hline $\mathrm{NH}_{4}(\mathrm{mg} / \mathrm{l})$ & $\begin{array}{c}3.98 \\
\pm 0.110151\end{array}$ & $\begin{array}{c}12.43 \\
\pm 4.780722\end{array}$ & $\begin{array}{c}5.97 \\
\pm 1.1159\end{array}$ & $0-5$ \\
\hline K (mg/l) & $\begin{array}{c}16.13 \\
\pm 0.602854\end{array}$ & $\begin{array}{c}8.26 \\
\pm 4.17314\end{array}$ & $\begin{array}{c}15.90 \\
\pm 0.132791\end{array}$ & $5-10$ \\
\hline Mg (mg/l) & $\begin{array}{c}15.52 \\
\pm 0.257164\end{array}$ & $\begin{array}{c}37.13 \\
\pm 12.31651\end{array}$ & $\begin{array}{c}16.6 \\
\pm 0.601775\end{array}$ & $6-24$ \\
\hline $\mathrm{Ca}(\mathrm{mg} / \mathrm{l})$ & $\begin{array}{c}82.92 \\
\pm 1.178474\end{array}$ & $\begin{array}{c}69.42 \\
\pm 8.476957\end{array}$ & $\begin{array}{c}51.06 \\
+18.41752\end{array}$ & $40-120$ \\
\hline $\mathrm{Cu}(\mathrm{mg} / \mathrm{l})$ & $\begin{array}{c}1.107 \\
\pm 0.149721\end{array}$ & $\begin{array}{c}0.440 \\
\pm 0.506491\end{array}$ & N.D & 2 \\
\hline $\mathrm{Fe}(\mathrm{mg} / \mathrm{l})$ & $\begin{array}{c}3.013 \\
\pm 0.193536\end{array}$ & $\begin{array}{c}1.463 \\
+1.065296\end{array}$ & $\begin{array}{c}0.388 \\
\pm 1.638726\end{array}$ & $2-5$ \\
\hline Mn (mg/l) & N.D & N.D & N.D & 0.2 \\
\hline $\mathrm{Pb}(\mathrm{mg} / \mathrm{l})$ & $\begin{array}{c}0.771 \\
\pm 0.067678\end{array}$ & $\begin{array}{c}0.528 \\
\pm 0.192513\end{array}$ & $\begin{array}{c}0.562 \\
\pm 0.12985\end{array}$ & 5 \\
\hline $\operatorname{Se}(\mathrm{mg} / \mathrm{l})$ & $\begin{array}{c}0.618 \\
\pm 0.091148\end{array}$ & $\begin{array}{c}1.226 \\
\pm 0.27933\end{array}$ & $\begin{array}{c}0.832 \\
\pm 0.107969\end{array}$ & 0.02 \\
\hline Zn (mg/l) & N.D & N.D & N.D & 2 \\
\hline
\end{tabular}

N.D: not detected

Chlorides in irrigation water are responsible for the most widespread crop toxicity. The chloride $(\mathrm{Cl}-)$ anion is present in all waters; chlorides are soluble and readily leach to drain water. Chlorides are essential for plant growth, although they may inhibit plant growth at high concentrations and may be highly toxic to some plant species (Ayers and Westcot, 1985). According to (Zaman et al., 2018) chloride in 
irrigation water is safe for all types of plants at a concentration below $70 \mathrm{ppm}$, whereas chloride concentrations between 70-140 ppm could be harmful for sensitive plants. Our results show that the chloride level in irrigation water from "Site 1" is safer for all plants compared to "site2" and "site3".

The results of water analysis showed that the values for nitrates in all sampling sites was found to be below the maximum permissible nitrate levels of $50 \mathrm{mg} / \mathrm{l}$ according to the EU directives related to quality of water (Nikolaou et al., 2020).

The sulfate ion is a significant contributor to the total salt content of irrigation waters and has fertility benefits for crops but high sulfate ions in irrigation water will reduce the supply of phosphorous to plants (Mohammed, 2016). The sulfate $\left(\mathrm{SO}_{4}{ }^{2-}\right)$ values in the water samples in "site 1" and "site 3" were below $200 \mathrm{mg} / \mathrm{l}$ which is the acceptable range according to Herrmann and Bucksch, (2014) whereas the sulfate concentration in "site 2" was $247.09 \mathrm{mg} / \mathrm{l}$ and thus exceeded the acceptable range.

Generally, the data revealed that the levels of almost all anions and cations detected in the water samples were in the ranges set by FAO for irrigation water. On the other hand, some values were outside the FAO recommended limits; these include nitrates $\left(\mathrm{NO}_{3}{ }^{-}\right)$in site 2 , ammonia $\left(\mathrm{NH}_{4}^{+}\right)$in sites 2 and 3, potassium $\left(\mathrm{K}^{+}\right)$in sites 1 and 3 and magnesium $\left(\mathrm{Mg}^{2+}\right)$ in site 2(Arshad and Shakoor, 1987).

In order to get more information about the quality of the irrigation water, different parameters, such as Sodium adsorption ratio (SAR), Kelly's Ratio (KR), percentage of sodium $(\mathrm{Na} \%)$ and Magnesium Ratio, were calculated and the data are depicted in Table (2).

Sodium adsorption ratio (SAR) has been usually used for evaluating the sodium hazard. SAR is the ratio of sodium to calcium and magnesium. The higher the SAR, the greater the sodium hazard (Alobaidy et al., 2010; Herrmann and Bucksch, 2014).

In the present work (Table 2), SAR value of the water samples varied from 1.33 to 3.61 and the electrical conductivity (EC) value of the water samples varied from 0.438 to $0.625 \mathrm{dS} / \mathrm{m}$; in this respect according to Aboukarima $\boldsymbol{e t}$ al., (2018) and by considering the combination of EC and SAR values, the water of the study area is suitable for irrigation. Also according to Nikolaou et al., (2020) the SAR values lower than 10 is considered excellent for agriculture.

Table (2): Calculated water quality parameters

\begin{tabular}{lccc}
\hline Parameter & Site 1 & Site 2 & Site 3 \\
\hline SAR & 1.33 & 3.61 & 2.49 \\
KR & 0.405 & 1.00 & 0.89 \\
\% Na & 33.39 & 59.75 & 50.58 \\
Mg ratio & 15.76 & 38.84 & 25.53 \\
\hline
\end{tabular}

Kelly's ratio measures sodium ion against calcium and magnesium ions, this ratio aims at determining the hazardous effect of sodium on water quality for irrigation purposes. According to Shah et al., (2019) Kelly's Ratio value showing more than 1 indicates more amount of sodium in water and thus it is not suitable for irrigation purposes. Data in Table (2) show that Kelly's ratio calculated for our study sites which 
ranged from 0.405 to 1.00 , so according to Shah et al., (2019) and based on KR values, all irrigation water samples are suitable for irrigation purpose.

The presence of excess sodium in the irrigation water can adversely impact soil structure, making plant growth difficult (Ewaid et al., 2019). The percentages of sodium (Na \%) (Table 2) recorded during this work showed good condition with preference to site 1 followed by site 3 and then site 2 .

In most water types, calcium and magnesium maintain a state of equilibrium and a high magnesium ratio $>50 \%$ has an adverse effect on the crop yield as the soil becomes more alkaline, and effect on the agricultural yield (Singh $\boldsymbol{e t}$ al., 2020). From data in Table 2 , the $\mathrm{Mg}$ ratio values in the three study sites were all low than $50 \%$ i.e. magnesium hazard ratio $<50 \%$, which is recognized as suitable for irrigation.

Table (3): Elements in surrounding agricultural soil

\begin{tabular}{|c|c|c|c|c|c|c|}
\hline \multirow[b]{2}{*}{ Element } & \multicolumn{2}{|c|}{$\begin{array}{c}\text { Kafr-Bahia } \\
\text { Site 1 } \\
\end{array}$} & \multicolumn{2}{|c|}{$\begin{array}{c}\text { Meit- Mohsen } \\
\text { Site } 2 \\
\end{array}$} & \multicolumn{2}{|c|}{$\begin{array}{l}\text { Al-Amereya } \\
\text { Site } 3\end{array}$} \\
\hline & Total & Available & Total & Available & Total & Available \\
\hline \multirow[t]{2}{*}{$\mathrm{Ca}$} & 17170 & 12930 & 19670 & 10080 & 239300 & 32230 \\
\hline & \pm 509.12 & \pm 91.92 & \pm 353.55 & \pm 7.07 & \pm 494.97 & \pm 162.63 \\
\hline \multirow[t]{2}{*}{$\mathrm{Mg}$} & 10930 & 1816 & 10960 & 1588 & 11400 & 1941 \\
\hline & \pm 91.92 & \pm 18.38 & \pm 21.21 & \pm 50.91 & \pm 332.34 & \pm 6.36 \\
\hline \multirow[t]{2}{*}{$\mathrm{Na}$} & 1282 & 1071 & 1681 & 817.6 & 1466 & 1944 \\
\hline & \pm 12.73 & \pm 13.44 & \pm 282.14 & \pm 37.76 & \pm 130.11 & \pm 25.46 \\
\hline \multirow[t]{2}{*}{$\mathrm{K}$} & 3962 & 846.6 & 4381 & 803.9 & 4115 & 717.6 \\
\hline & \pm 26.87 & \pm 16.55 & \pm 296.28 & \pm 1.91 & \pm 108.19 & \pm 1.70 \\
\hline \multirow[t]{2}{*}{$\mathrm{Cu}$} & 66.77 & 11.12 & 68.45 & 6.999 & 13.24 & $6.3 \pm 0.49$ \\
\hline & \pm 2.28 & \pm 2.04 & \pm 1.19 & \pm 0.06 & \pm 0.85 & \\
\hline \multirow[t]{2}{*}{$\mathrm{Fe}$} & 45570 & 894.9 & 52160 & $993 \pm 1.34$ & 12940 & 423.4 \\
\hline & \pm 304.06 & \pm 3.61 & \pm 465.93 & & \pm 42.43 & \pm 4.67 \\
\hline \multirow[t]{2}{*}{$\mathrm{Zn}$} & 108.6 & N.D & 75.83 & N.D & N.D & N.D \\
\hline & \pm 6.08 & & \pm 23.17 & & & \\
\hline \multirow[t]{2}{*}{$\mathrm{Mn}$} & 966.8 & 76.01 & 934.5 & 6.498 & 258.9 & N.D \\
\hline & \pm 23.48 & \pm 1.41 & \pm 22.84 & \pm 0.78 & \pm 5.59 & \\
\hline \multirow[t]{2}{*}{$\mathrm{Cr}$} & 46.77 & N.D & 46.24 & N.D & N.D & N.D \\
\hline & \pm 0.87 & & \pm 0.37 & & & \\
\hline \multirow[t]{2}{*}{$\mathrm{Ni}$} & 35.61 & N.D & 31.99 & N.D & N.D & N.D \\
\hline & \pm 2.40 & & \pm 2.56 & & & \\
\hline $\mathrm{Pb}$ & N.D & N.D & N.D & N.D & N.D & N.D \\
\hline $\mathrm{Cd}$ & N.D & N.D & N.D & N.D & N.D & N.D \\
\hline
\end{tabular}

N.D: not detected

Agricultural soil samples from the three studied sites were analyzed to determine the total and available concentrations of some elements including $\mathrm{Ca}, \mathrm{Mg}, \mathrm{Na}, \mathrm{K}, \mathrm{Cu}, \mathrm{Fe}$, $\mathrm{Zn}, \mathrm{Mn}, \mathrm{Cr}, \mathrm{Ni}, \mathrm{Pb}$ and $\mathrm{Cd}$. The data for soil analysis are given in table (3). The concentrations of $\mathrm{Ca}, \mathrm{Mg}, \mathrm{Na}, \mathrm{K}, \mathrm{Cu}, \mathrm{Fe}, \mathrm{Zn}$, and $\mathrm{Mn}$ in the three studied sites were compared to the maximum allowable concentration (MAC) of elements in soil .The total 
Fe concentration in the three studied sites exceeded the maximum allowable concentration (1000 mg/kg) (Naggar et al., 2014), whereas the available Fe concentrations were within the limits. The total and available concentrations of copper were within the maximum allowable limit $(100 \mathrm{mg} / \mathrm{Kg})$ (Naggar et al., 2014). The total and available concentrations of zinc also were below the maximum allowable limit (300 $\mathrm{mg} / \mathrm{Kg}$ ) (Hegazy et al., 2011). The MAC value for Mn in agricultural soils is estimated at 1500 ppm (Naggar et al., 2014), in the present work all sites showed acceptable concentration for $\mathrm{Mn}$.

In general, the most common heavy metals usually found at contaminated sites, in order of abundance are $\mathrm{Pb}, \mathrm{Cr}, \mathrm{As}, \mathrm{Ni}, \mathrm{Zn}, \mathrm{Cd}, \mathrm{Cu}$, and $\mathrm{Hg}$. These metals are capable of decreasing crop production due to the risk of bioaccumulation and biomagnification in the food chain (Wuana and Okieimen, 2011). In the present study $\mathrm{Ni}$ and $\mathrm{Cr}$ were recorded at low concentrations in sites 1 and 2 and were not detected in site 3 noting that the maximum allowable limit for $\mathrm{Ni}$ is $50 \mathrm{ppm}$ and that of $\mathrm{Cr}$ is $100 \mathrm{ppm}$ (Khalid et al., 2017). Also, $\mathrm{Pb}$ and $\mathrm{Cd}$ were not detected in all samples collected in the present study.

Metals/metalloids concentrations in the soil are increasing at alarming rate and affect plant growth, food safety, and soil microflora. However, metals like $\mathrm{Cu}, \mathrm{Mn}, \mathrm{Co}$, $\mathrm{Zn}$, and $\mathrm{Cr}$ are required in trace amounts by plants for their metabolic activities(Onosemuode et al., 2016).

\section{CONCLUSION}

Monitoring of water quality is an essential task as water quality has numerous complex interactions, direct and indirect effects on soil, plants, humans and all kind of life. It can be concluded that no contamination of soil was observed and this is a result of the use of irrigation water meeting the quality criteria along with proper application of fertilizers. It is recommended to regularly monitor the quality of water used for irrigation as well as the soil quality in order to avoid any drop in agriculture production.

\section{REFERENCES}

Abdel-Satar, A.M.; Ali, M.H. and Goher, M.E. (2017). Indices of water quality and metal pollution of Nile River, Egypt. Egypt. J. Aquat. Res., 43(1): 21-29.

Aboukarima, A.M.; Al-Sulaiman, M.A. and El Marazky, M.S.A. (2018). Effect of sodium adsorption ratio and electric conductivity of the applied water on infiltration in a sandy-loam soil. Water SA., 44 (1): 105-110.

Abuzaid, A. (2017). Soil quality indicators in Al-Qalyubia Governorate as affected by long-term wastewater irrigation. Egypt. J. Soil Sci., 58:1 -11.

Alobaidy, A.H.M.J.; Al-Sameraiy, M. A.; Kadhem, A.J. and Majeed, A.A. (2010). Evaluation of Treated Municipal Wastewater Quality for Irrigation. J. Environ. Prot., 1: $216-225$.

APHA, (2005). Standard Methods for the Examination of Water and Wastewater. 21 ${ }^{\text {st }}$ Edition, American Public Health Association/ American Water Works Association/Water Environment Federation, Washington DC.

Arshad, M. and Shakoor, A. (1987). Irrigation water quality requirements, Water International., 12 (1): 15-18. 
Angelakis, A.N.; Zaccaria, D.; Krasilnikoff, J.; Salgot, M.; Bazza, M.; Roccaro, P.; Jimenez, B.; Kumar, A.; Yinghua, W.; Baba, A.; Harrison, J.A.; GardunoJimenez, A. and Fereres, E., (2020). Irrigation of world agricultural lands: Evolution through the Millennia. Water (Switzerland) 12.

Ayers, R.S. and Westcot, D.W. (1985). Water Quality for Agriculture. FAO UNITED NATIONS,Rome,Italy 97

El-Hassanin, A.S.; Samak, M.R.; Radwan, S.R. and El-Chaghaby, G.A., (2020). Preparation and characterization of biochar from rice straw and its application in soil remediation. Environ. Nat. Resour. J., 18: 283-289.

El-Sheekh, M.M. (2009). River Nile Pollutants and Their Effect on Life Forms and Water Quality, in: The Nile: Origin, Environments, Limnology and Human Use. p. 818.

El Gohary, R. (2015). Agriculture, industry, and wastewater in the Nile Delta. Int. J. Sci. Res. Agric. Sci., 2: 159-172.

Ewaid, S.H.; Kadhum, S.A.; Ali, S. and Salih, R.M. (2019). Development and evaluation of irrigation water quality guide using IWQG V . 1 software : A case study of Al-Gharraf Canal ,. Environ. Technol. Innov., 13:224-232.

Goher, M.E.; Abdo, M.H.; Mangood, A.H. and Hussein, M.M. (2015). Water quality and potential health risk assessment for consumption of Oreochromis niloticus from El-Bahr El-Pharaony Drain, Egypt. Fresenius Environ. Bull., 24: 3590-3602.

Hegazy, A. K.; Abdel-Ghani, N.T. and El-Chaghaby, G. A. (2011). Phytoremediation of industrial wastewater potentiality by Typha domingensis. Int. J. Environ. Sci. Technol., 8: 639-648.

Herrmann, H. and Bucksch, H. (2014). Irrigation Water. Dict. Geotech. Eng. Geotech., 1: 750-750.

Hoque, M.I.; Islam, M.A. and Morshed, M.N., (2020). Water quality of Barishal sadar upazila in Bangladesh for drinking, irrigation, aquaculture and livestock consumption. Asian J. Med. Biol. Res., 6: 44-55.

Khalid, S.; Shahid, M.; Niazi, N.K.; Murtaza, B.; Bibi, I. and Dumat, C. (2017). A comparison of technologies for remediation of heavy metal contaminated soils. J. Geochemical Explor., 182: 247-268.

Malakar, A.; Snow, D.D. and Ray, C. (2019). Irrigation water quality-A contemporary perspective. Water., 11: 1-24.

Mohammed S. L.A. (2016). Assessment of the Irrigation Water Quality for Al- Kifl River in Al-Hindya City. J. Babylon Univ. Sci., 24(1): 266-27.

Naggar, Y. Al.; Naiem, E.; Mona, M. and John, P. (2014). Metals in agricultural soils and plants in Egypt. Toxicolog.Environ. Chem., 37-41.

Nikolaou, G.; Neocleous, D. and Christophi, C. (2020). Irrigation Groundwater Quality Characteristics : A Case Study of Cyprus. Atmosphere., 11: 1-15.

Onosemuode, C.L.; Ataikiru, T.E. and Oghama, O. (2016). Assessment of Water Suitability for Irrigation in Keffi, Nasarawa State, Nigeria. Int. J. Sci., 2: 11-19.

Rashad, S.; El-Hassanin, A.S.; Mostafa, S.S.M. and El-Chaghaby, G.A. (2019a). Cyanobacteria cultivation using olive milling wastewater for bio-fertilization of celery plant. Glob. J. Environ. Sci. Manag., 5(2): 167-174.

Rashad, S.; Moneem, M.A.; El-Chaghaby, G.A. and Abdel-Kader, S.F. (2019b). 
Monitoring water quality and plankton distribution in the river Nile around el-Maadi area in Egypt during 2018. Egypt. J. Aquat. Biol. Fish., 23(5): 81-87.

Shah, B.; Kansara, B.; Shankar, J.; Soni, M. and Bhimjiyani, P. (2019). Reckoning of water quality for irrigation and drinking purposes in the konkan geothermal provinces, Maharashtra, India. Groundw Sustain Dev.

Shahinasi, E. and Kashuta, V. (2008). Irrigation water quality and its effects upon soil. Water., 27:1-6

Singh, K.K.; Tewari, G. and Kumar, S. (2020). Evaluation of Groundwater Quality for Suitability of Irrigation Purposes: A Case Study in the Udham Singh Nagar, Uttarakhand. J. Chem., $6924026: 1-15$.

Wang, H.; He, P.; Shen, C. and Wu, Z. (2019). Effect of irrigation amount and fertilization on agriculture non-point source pollution in the paddy field. Environ.Sci Pollut. Res., 26: 10363-10373.

Wuana, R.A. and Okieimen, F.E. (2011). Heavy Metals in Contaminated Soils: A Review of Sources, Chemistry, Risks and Best Available Strategies for Remediation. ISRN Ecol., (2): 1-20.

Zaman, M.; Shahid, S.A. and Heng, L. (2018). Irrigation Water Quality BT Guideline for Salinity Assessment, Mitigation and Adaptation Using Nuclear and Related Techniques, in: Zaman, M., Shahid, S.A., Heng, L. (Eds.), . Springer International Publishing, Cham, pp., 113-131. 